\title{
Settlement Behavior Evaluation of Soft-Clay Layer Reinforced with Sand Piles
}

\author{
Serpil Erden ${ }^{1}$, Kaveh Dehghanian ${ }^{2}$ \\ ${ }^{1,2}$ Department of Civil Engineering, Faculty of Engineering, Istanbul Aydin University, Istanbul, Turkey
}

\begin{abstract}
In this study, the performances of the sand piles in Istanbul's Bağcılar and Zeytinburnu districts has been analyzed using Finite Element Method (FEM). Single and group (triple) piles with various length/diameter ratios (L/D) were placed in the water-saturated soft clay soil. Sand piles were modeled in various L/D ratios $(10,5.71$, and 8.57). The distance between the piles was chosen as 2 meters and the group effect was also investigated. A uniformly distributed load of $162 \mathrm{kN} / \mathrm{m}^{2}$ is placed on the ground. In addition, the soil was modeled with the Soft-Soil soil model, the hardening soil model for the infill part, and the sand piles with the Mohr-Coulomb soil model. According to the results, the settlement of the soil decreases by $52.8 \%$ for a single pile with an L/D ratio of 8.57. However, the best L/D ratio for triple piles was found to be 5.71. In this case, the settlement decreases by $52.8 \%$ compared to the pileless situation. Finally it was concluded that the model with the L/D ratio of 8.57 reduced settlement in the best and the most efficient way.
\end{abstract}

KEYWORDS: Sand piles, finite element method, clayey soil, hardening-soil model, soft-soil model.

\section{INTRODUCTION}

Clayey soils tend to settle excessively due to their lowstrength and high compressibility. Therefore, it leads to stability problems. Sand piles are one of the methods used to reduce settlement in soft clay soils, increase bearing capacity and accelerate the consolidation process of clayey soils. This study was carried out to analyze the behavior of sand piles placed in a saturated clay bed under load. Analyzes were done using the finite element analysis method Plaxis Version 8-2D.

In the literature, there are studies conducted by placing sand piles in clayey soil, using finite element analysis methods and small scale experiments. Samadhiya,N et.al. [1], investigated the load settlement behavior for a single sand pile in CL class clayey soil. The tests were conducted to investigate the load settlement behavior of the clayey soil individually and the behavior of the piles placed in the soil. In Rajbut et.al [2] study, Distance/ Diameter (S/D) ratios (22.5-3) and Length/Diameter (L/D) ratios (3-5-7) were selected, one of the 7 pile groups was selected as a centeral pile and the L/D and S/D ratios were studies. In this paper, laboratory model tests were applied. Finally, it was observed that the bearing capacity increases as the distance between the piles decrease.

Hasan and Samadhiya [3], conducted experimental model tests to investigate the behavior of piles under short-term loading in order to increase the load bearing capacity and reduce settlements in soft clay soils.

Hasan and Samadhiya [4], Study conducted experiments to examine the swelling effect of the sandy piles As a result of laboratory experiments, load settlement behavior was obtained for sand piles. In the results of working It was found that the bearing capacity increased when the entire floor area was loaded. Obtained test results were compared with numerical analysis results.

Galil et.al. [5] investigated the behavior of a raft foundation resting on clayey soil reinforced with sand piles under longterm loading. According to the results of the threedimensional finite element analysis, it was observed that the sand piles were used to strengthen the clayey soil under the raft foundation and the bearing capacity, so settlement and bending moment of the raft foundation wa improved considerably.

In the study of Naseer et. al. [6], the effects of sand piles placed on clayey soils modeled on a small scale were investigated by experimental studies. In the research, the effects of sand piles with different L/D ratios on the ground and the shear strength of the piles were investigated. The results show that the maximum strength is at $\mathrm{L} / \mathrm{D}=4$ and as the L/D ratio increases, the loading capacity decreases due to soil swelling. The purpose of Safin [7], in his 2020's study, is to evaluate the deformation of a group of sand piles under load in a saturated clayey soil. This study was carried out using computational methods to examine the interactions of a group of sand piles with the clayey soil in the free state without calculating their working together. As a result of the study, despite the improvement of the deformation properties of sand piles in water-saturated soil, the deformation reaches large values with precipitation. This is because deformation occurs before the sand piles are added. 


\section{MATERIAL AND METHOD}

\section{A. Geotechnical Evaluation}

In the study, a saturated clayey soilisplaced in two layers. The soil is classified as CL (low plasticity clay) according to USCS classification system. Soil input data were obtained from geotechnical report of Istanbul Province, Zeytinburnu District. Embankment layer is comprised of Garvelly soil, the data obtained from the geotechnical report of Istanbul Province, Bağcllar District. In Figure 1, the soil profile used for the calculations is shown.
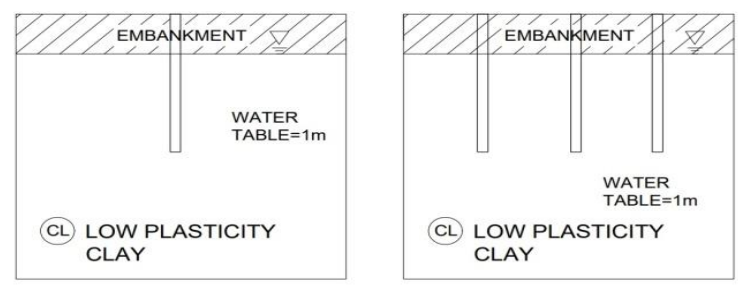

Figure 1:Soil Profile

The permability coefficient $10^{-2} \mathrm{~cm} / \mathrm{sec}(86.4 \mathrm{~m} /$ day $)$ was chosen for the embankment layer [8]. The material properties for the clay layer are shown in Table 1. The input parameters used in this study are given in Table 2.

Table 1: Soil parameters used in PLAXIS

\begin{tabular}{|l|l|}
\hline Definition & Embankment \\
\hline Soil Model & Hardening- Soil Model \\
\hline Drainage Condition & Undrained \\
\hline Unit volume weight $\left(\mathrm{kN} / \mathrm{m}^{3}\right)$ & 15.00 \\
\hline Permability $(\mathrm{m} /$ day $)$ & 86.4 \\
\hline $\mathrm{E}_{50}\left(\mathrm{kN} / \mathrm{m}^{2}\right)$ & 9806.65 \\
\hline $\mathrm{E}_{\text {oed }}\left(\mathrm{kN} / \mathrm{m}^{2}\right)$ & 9806.65 \\
\hline $\mathrm{E}_{\text {ur }}\left(\mathrm{kN} / \mathrm{m}^{2}\right)$ & 29419.95 \\
\hline Poisson's ratio, $v$ & 0.41 \\
\hline $\begin{array}{l}\text { Effective internal friction } \\
\text { angle }(\text { Degree })\end{array}$ & 20 \\
\hline Cohesion, c $\left(\mathrm{kN} / \mathrm{m}^{2}\right)$ & 4.9 \\
\hline Expansion angle, $\psi$ & 0 \\
\hline
\end{tabular}

Table 2: Input parameters used in PLAXIS

\begin{tabular}{|l|l|}
\hline Definition & Low plasticity clay (CL) \\
\hline Soil Model & Soft- Soil Model \\
\hline Drainage Condition & Undrained \\
\hline $\begin{array}{l}\text { Dry unit weight } \\
\left(\mathrm{kN} / \mathrm{m}^{3}\right)\end{array}$ & 15.99 \\
\hline $\begin{array}{l}\text { Saturated unit } \\
\text { weight }\left(\mathrm{kN} / \mathrm{m}^{3}\right)\end{array}$ & 18.39 \\
\hline $\begin{array}{l}\text { Modulus of elasticity, E } \\
(\mathrm{kN} / \mathrm{m} 2)\end{array}$ & 16960 \\
\hline Permability (m/day) & $39.19104 \times 10^{-6}$ \\
\hline Poisson's ratio $v$ & 0.30 \\
\hline $\begin{array}{l}\text { Effective internal } \\
\text { friction angle (Degree) }\end{array}$ & 8.43 \\
\hline Cohesion, c $\left(\mathrm{kN} / \mathrm{m}^{2}\right)$ & 51 \\
\hline Compression index, $\tilde{\lambda}$ & 0.066385869 \\
\hline Swelling index $\tilde{\kappa}$ & 0.013277173 \\
\hline 1122 &
\end{tabular}

The sand used in this study is classified as SP (poorlygraded sand).According to USCS, the sand particles are finer than $4.75 \mathrm{~mm}$ sieve[2].In this study, dry unit weight for sand as selected as $15.5 \mathrm{kN} / \mathrm{m}^{3}$ [6], modulus of elasticity; $80000 \mathrm{kN} / \mathrm{m}^{2}$ [9], cohesion; $1.96 \mathrm{kN} / \mathrm{m}^{2}$ [10], and permability coefficient was selected as $8.64 \mathrm{~m} /$ day [8]. Parameters for sand piles are given in Table 3. The sand piles were modeled as drained with the Mohr Cloumb Model. In this study study, a single pile and a triple group piles were selected and loaded with a uniformly distributed load of $162 \mathrm{kN} / \mathrm{m}^{2}$.

Table 3: Sand pile parameters used in the modelling.

\begin{tabular}{|l|l|}
\hline Definition & sand pile \\
\hline Model & Mohr Cloumb Model \\
\hline Drainage Condition & Undrained \\
\hline Dry unit weight $\left(\mathrm{kN} / \mathrm{m}^{3}\right)$ & 15.5 \\
\hline $\begin{array}{l}\text { Saturated unit } \\
\text { weight }\left(\mathrm{kN} / \mathrm{m}^{3}\right)\end{array}$ & 18.0 \\
\hline Cohesion c $\left(\mathrm{kN} / \mathrm{m}^{2}\right)$ & 1.96 \\
\hline $\begin{array}{l}\text { Modulus of elasticity E } \\
\left(\mathrm{kN} / \mathrm{m}^{2}\right)\end{array}$ & 80000 \\
\hline Poisson's ratio $v$ & 0.3 \\
\hline $\begin{array}{l}\text { Effective internal friction } \\
\text { angle (Degree) }\end{array}$ & 30 \\
\hline Expansion angle $\psi$ & 1 \\
\hline Permability $(\mathrm{m} /$ day) & 8.64 \\
\hline
\end{tabular}

In research, the distance between the sand piles is usually expressed with "S", while the diameter of the sand pile is expressed with "D". Likewise, L/D is the (length/diameter) ratio for the sand pile. In this study, three different models were being analyzed as it is shown in Table 4 .

Table 4: Properties of sand pile

\begin{tabular}{|l|l|l|l|l|}
\hline Model & $\begin{array}{l}\text { Height } \\
(\mathrm{cm})\end{array}$ & $\begin{array}{l}\text { Diameter } \\
(\mathrm{cm})\end{array}$ & $\begin{array}{l}\text { L/D } \\
(\text { Length/ } \\
\text { Diamete } \\
\mathrm{r})\end{array}$ & $\begin{array}{l}\text { Distance } \\
\mathrm{S}(\mathrm{m})\end{array}$ \\
\hline $\begin{array}{l}\text { Model } \\
1\end{array}$ & 800 & 80 & 10 & $\mathrm{~S}=2$ \\
\hline $\begin{array}{l}\text { Model } \\
2\end{array}$ & 300 & 35 & 8,57 & $\mathrm{~S}=2$ \\
\hline $\begin{array}{l}\text { Model } \\
3\end{array}$ & 400 & 70 & 5,71 & $\mathrm{~S}=2$ \\
\hline
\end{tabular}

\section{B. Finite Element Method}

Finite element method is a numerical method used in solving engineering problems. In addition to the fact that the method started to be used in the 1950s, it is also used in the fields of medicine and dentistry apart from engineering fields[11].For the soil modeled with the soft-soil soil modelin finite element model, the possible deformations on the single pile and group piles are shown in Figure 2. 


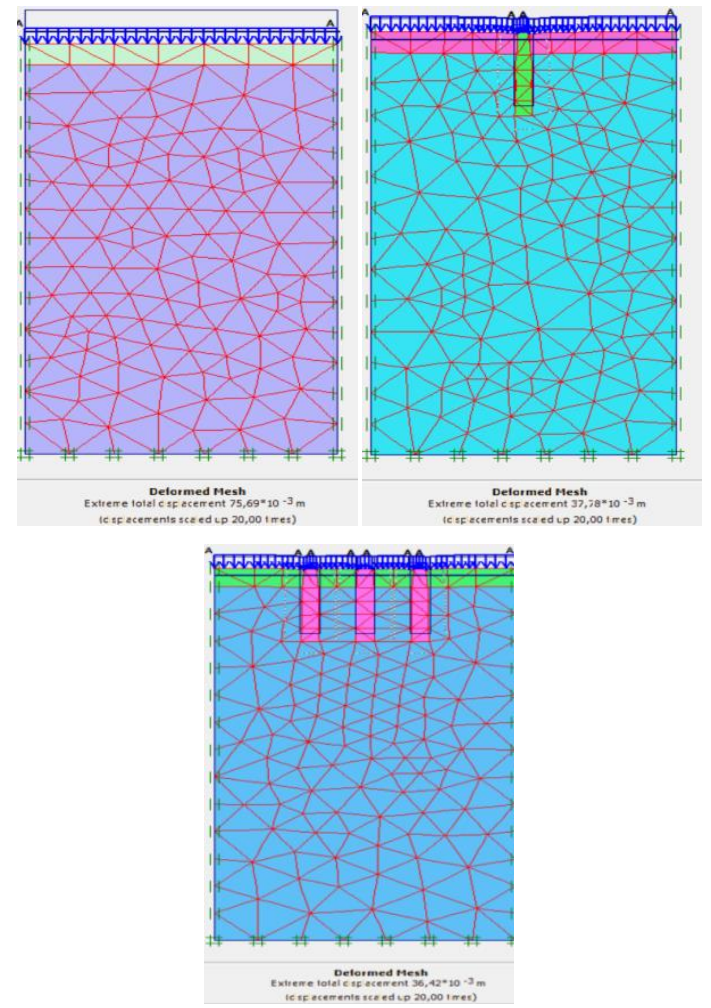

Figure 2: Vertical deformation values in PLAXIS -2D

\section{Material models}

a. Hardening Soil Model

The hardening soil model is a model used to simulate the behavior of soft and hard soils. In the hardening soil model, the stiffness of the soil is modeled using three different stiffnesses. In this modeling, $\mathrm{E}_{50}$, triaxial loading stiffness, $\mathrm{E}_{\mathrm{ur}}$, triaxial unloading stiffness and $\mathrm{E}_{\mathrm{oed}}$ are used as oedometer loading stiffness input parameters. It is a hardening model that is not affected by the softening caused by the expansion of the ground. It is also an isotropic hardening model [12].

\section{b. Soft-Soil Model}

This soil model is a soil model designed for primary compaction of clayey soils in normal consolidation. This soil model should be used especially where compaction is important [12].

\section{c. Mohr-Coulomb Zemin Model}

It is a model used to perform a quick and simpler analysis of any soil problem. Good results can be obtained when soil data is good, but different models can be used for further analysis [12].

\section{Nodes}

In the finite element method, while calculating the clusters by dividing the clusters into triangular elements, the 15 -node element is shown by 15 nodes, a 6-node element is shown by 6 nodes, and adjacent elements are connected with common nodes. In the calculation phase, the displacements at the nodes are calculated. In the study, the element was chosen as 15 nodes during the creation of the mesh [12].

\section{RESULTS}

Settlements in the selected soil was analyzedand the performance of sandy pile within the scope of the geotechnical report was investigated and the following results were obtained.

1) ) When the soil is under uniform load without piles, the settlement is $75.69 \times 10^{-3} \mathrm{~mm}$. In case of single pile, settlement is $43.29 \times 10^{-3} \mathrm{~mm}$ for L/D:10 and $42.8 \%$ decrease was observed compared to the case without piles. For $\mathrm{L} / \mathrm{D}: 8.57$, it is $35.68 \times 10^{-3} \mathrm{~mm}$, and there is a $52.8 \%$ decrease in settlement compared to the pileless condition. For $\mathrm{L} / \mathrm{D}: 5.71$, it is $37.11 \times 10^{-3} \mathrm{~mm}$, with a reduction of up to $50.9 \%$ in settlement compared to the pileless situation.

2) In the case of triple group piles, the settlement is $46.41 \times 10^{-3} \mathrm{~mm}$ for L/D:10 and $38.6 \%$ decrease was observed compared to the case without piles. For L/D:8.57, it is $36.90 \times 10^{-3} \mathrm{~mm}$ and $51.2 \%$ reduction was observed compared to the pileless condition. The settlement is obtained as $35.66 \times 10^{-3} \mathrm{~mm}$ for $\mathrm{L} / \mathrm{D}: 5.71$ and decreased by $52.8 \%$ compared to the pileless condition.

3) As a result of the comparison, the optimum L/D ratio of the single pile is 8.57 and the best L/D ratio for the group piles is is 5.71. Also, the amount of settlement for both cases is very close to each other. The results are summarized in Table

5.

Table 5: PLAXIS-2D Analysis Results

\begin{tabular}{|c|c|c|c|c|c|c|c|}
\hline \multicolumn{8}{|l|}{ LOW PLASTIC CLAY(CL) } \\
\hline \multirow{3}{*}{ SITUATION } & \multirow{3}{*}{ PILELESS } & \multicolumn{3}{|c|}{ SINGLE PILE } & \multicolumn{3}{|c|}{ TRIPLE PILE } \\
\hline & & \multicolumn{3}{|c|}{ Length/Diameter (L/D) } & \multicolumn{3}{|c|}{ Length/Diameter (L/D) } \\
\hline & & 10 & 8.57 & 5.71 & 10 & 8.57 & 5.71 \\
\hline $\begin{array}{l}\text { EFFECTIVE } \\
\left(\mathrm{kN} / \mathrm{m}^{2}\right)\end{array}$ & -158.88 & -149.04 & -146.83 & -148.4 & -153.31 & -146.05 & -147.58 \\
\hline VERTICAL DISPLACEMENTS (m) & $75.69 \times 10^{-3}$ & $43.29 \times 10^{-3}$ & $35.68 \times 10^{-3}$ & $37.11 \times 10^{-3}$ & $46.41 \times 10^{-3}$ & $36.90 \times 10^{-3}$ & $35,66 \times 10^{-3}$ \\
\hline SHEAR STRAIN S(\%) & $385.17 \times 10^{-3}$ & 2.48 & 2.93 & 2.21 & 2.34 & 4.21 & 2.06 \\
\hline TOTAL STRESES $\left(\mathrm{kN} / \mathrm{m}^{2}\right)$ & -525.29 & -525.08 & $-525,35$ & -525.4 & -525.01 & -525.36 & -525.29 \\
\hline DEFORMED MESH (m) & $75.69 \times 10^{-3}$ & $43.73 \times 10^{-3}$ & $36, .17 \times 10^{-3}$ & $37.78 \times 10^{-3}$ & $47.04 \times 10^{-3}$ & $38,25 \times 10^{-3}$ & $36.42 \times 10^{-3}$ \\
\hline
\end{tabular}




\section{THANKS}

The geotechnical report was obtained from Tünges Engineering corporation. We would like to appreciate their support throughout of this study.

\section{REFERENCES}

1. Samadhiya, N., Maheshwari, P., Zsaki, A., Basu, P., \& Kundu, A. (2009). Strengthening of clay by geogrid reinforced granular pile. International Journal of Geotechnical Engineering, 3(3), 377386.

2. Rajput, D., Kumar, R., Jain, P. K., \& Chandrawanshi, S. (2016). Load-Settlement Behaviour of Soft Soil Reinforced with Sand Piles. International Research Journal of Engineering and Technology (IRJET), 3, 1303-8.

3. Hasan, M., \& Samadhiya, N. K. (2016). Experimental and numerical analysis of geosynthetic-reinforced floating granular piles in soft clays. International Journal of Geosynthetics and Ground Engineering, 2(3), 1-13.

4. Hasan, M., \& Samadhiya, N. K. (2018). Soft soils improvement by granular piles reinforced with horizontal geogrid strips. International Journal of Geotechnical Engineering, 12(1), 101-108.

5. Galil, A. M. A., Youssef, T. A., \& Elsalhy, M. I.(2019). Performance Of Rigid Raft Foundation Resting On Soft Clay Improved By Granuler Piles.

6. Naseer, S., Faiz, M. S., Iqbal, S., \& Jamil, S. M. (2019). Laboratory and numerical based analysis of floating sand columns in clayey soil. International Journal of Geo-Engineering, 10(1), 1-16.

7. Safin, D. R. (2020, November). Experimental studies of a weak clay base reinforced with sand piles. In IOP Conference Series: Materials Science and Engineering (Vol. 962, No. 3, p. 032020). IOP Publishing.

8. Evirgen, B., Onur, M. I., Tuncan, M., \& Tuncan, A. (2015). Determination of the freezing effect on unconfined compression strength and permeability of saturated granular soils. GEOMATE Journal, 8(16), 1283-1287.

9. Calik, O. (2018). Numerical analysis of reinforced walls (floors) (Master's thesis, Istanbul Gelisim University Institute of Science and Technology).

10. Günaydın, O., Alpyıldız, S., \& Akkuş, Ç. (2014). Effect Of Cut Speed On Cut Resistance Parameters In SP (Bad Rated Medium-Fiın Sand) Solls. Selcuk University Journal of Engineering, Science and Technology, 2 (1), 1-8.

11. Guler, M., \& Sadri, S. EN (2015). General Information About The Finite Element Method. Ordu University Journal of Science and Technology, 5 (1), 56-66. 12. PLAXIS-2D User Manual,(2021). "Plaxis 2D
Version 8 Material Models Manual" 